\title{
Diabetes type 1 and pregnancy outcome at University Hospital Center Split - a retrospective study
}

\section{Trudnoća i porođaj uz dijabetes melitus ovisan o inzulinu u KBC-u Split - retrospektivno istraživanje}

\author{
Doris Praprotnik", Damir Roje', Maja Radman², Marko Vulić', Zoran Meštrović1
}

${ }^{1}$ Clinical Department of Obstetrics and Gynecology, University Hospital Center Split, Croatia

${ }^{2}$ Clinical Department of Endocrinology and Diabetes, University Hospital Center Split, Croatia
Abstract. Aim: To evaluate the prevalence, assessment, and perinatal outcome of pregnancies complicated with diabetes mellitus type 1 (DM type 1 ) at a tertiary perinatal center in the town of Split, Dalmatia County. Materials and methods: The investigation was designed as a retrospective cohort study. All pregnant women with DM type 1 that were supervised and gave birth at Clinical Department of Obstetrics and Gynecology, Split University Hospital Center during a 7-year period (2009-2015), including those diagnosed in 2015 and having delivered in 2016, were included in the study group. Data were collected by the census method from legal protocol books. Control group included DM type 1-free pregnancies entered in the same protocol books just following a particular study woman, if meeting all inclusion and exclusion criteria. Results: There were 70 DM type 1 pregnancies, accounting for $0.2 \%$ of all deliveries. DM type 1 group newborns were statistically heavier (3650 \pm 605 vs. $3428 \pm 591 \mathrm{~g} ; p=0.031)$, more frequent large for gestational age ( $24.3 \%$ vs. $5.7 \%$; $p=0.002)$ and macrosomic ( $24.3 \%$ vs. $10 \% ; p=0.033$ ). Compared to control group, DM type 1 women had a significantly higher delivery rate in the $37^{\text {th }}$ to $39^{\text {th }}$ week of gestation $(84.3 \%$ vs. $58.6 \% ; p=0.001)$ and higher cesarean section rate (61.4\% vs. $32.9 \% ; p=0.001)$. Conclusion: DM type 1 significantly influences perinatal outcome. It requires multidisciplinary approach and complete supervision should be provided at specialized centers. Respecting the fetal origin of adult diseases theory, inappropriate protocol(s) and/or individual decision(s) can have many health consequences throughout newborns life, which highlights DM type 1 pregnancies to a public health level issue.

Key words: cesarean section; diabetes mellitus; fetal macrosomia; pregnancy

Sažetak. Cilj: Ispitati učestalost, način nadzora i perinatalni ishod trudnoća kompliciranih dijabetes melitusom ovisnim o inzulinu (DM tip 1) u tercijarnom perinatalnom centru u Splitu. Materijali i metode: Istraživanje je osmišljeno kao retrospektivna kohortna studija. Popisnom su metodom uključene sve trudnice $s$ dijabetes melitusom ovisnim o inzulinu koje su nadzirane i rodile su u Klinici za ženske bolesti i porode KBC-a Split u sedmogodišnjem periodu, od prosinca 2009. do prosinca 2015. godine, uključujući i one dijagnosticirane u 2015. godini koje su rodile početkom 2016. godine. Kontrolnu je skupinu sačinjavao jednak broj fizioloških trudnoća upisanih u Rađaonski protokol - neposredno nakon poroda pojedine ispitanice sa šećernom bolešću uzimani su podatci prve sljedeće rodilje iz kontrolne skupine. Obje skupine ispitanica zadovoljavaju kriterije uključenja i isključenja. Rezultati: U Klinici je analizirano 70 trudnoća i porođaja s dijabetes melitusom ovisnim o inzulinu, što je sačinjavalo $0,2 \%$ ukupnih poroda. Novorođenčad majki s DM-om tipa 1 bila je statistički značajno teža od kontrolne skupine ( $3650 \pm 605$ vs. $3428 \pm 591 \mathrm{~g} ; p=0,031)$, češće je bila hipertrofična $(24,3 \%$ vs. $5,7 \% ; p=0,002)$ i makrosomna $(24,3 \%$ vs. $10 \% ; p=0,033)$. U usporedbi s kontrolnom skupinom, $u$ ispitivanoj skupini bilo je statistički značajno više porođaja između 37 . i 39. tjedna trudnoće $(84,3 \%$ vs. $58,6 \% ; p=0,001)$, uz značajno višu stopu dovršenja poroda carskim rezom $(61,4 \%$ vs. $32,9 \% ; p=0,001)$. Zaključak: DM tip 1 značajno utječe na perinatalni ishod, zahtijeva multidisciplinaran pristup i nadzor u visokospecijaliziranim

http://hrcak.srce.hr/medicina 
centrima. Uzimajući u obzir da čimbenici intrauterinog života imaju ulogu i u razvoju mnogih bolesti u djece i odrasloj dobi, neadekvatni postupci $\mathrm{i}$ individualne odluke mogu pratiti dijete tijekom života, a i pogoršati postojeće majčine komplikacije, što ovoj bolesti daje još veću važnost.

Ključne riječi: carski rez; dijabetes melitus; fetalna makrosomija; trudnoća

\section{INTRODUCTION}

Diabetes mellitus type 1 (DM type 1 ) is a chronic autoimmune disease. Pancreatic $\beta$-cell damage progresses with time to complete insulin deficiency. According to the World Health Organization reports, the prevalence of DM in Croatia is $9.9 \%$, of which DM type 1 accounts for only $5 \%$ $10 \%{ }^{1}$. In the last few decades, an alarming increase has been recorded in the prevalence of DM in adolescents and women of fertile age $\mathrm{e}^{2-3}$. In Croatia, about 50 DM type 1 patients, or slightly less than $1 \%$, deliver babies per year ${ }^{4}$. The specific dynamics of metabolic changes in pregnancy, induced by hormonal activity of the placenta, significantly modify maternal blood glucose regulation and thus also her insulin requirements. All complications of DM type 1 that develop irrespective of pregnancy are potentiated in these new circumstances and can have undesirable consequences for both the mother and the fetus. In diabetic pregnant women, poor metabolic control is associated with a higher rate of spontaneous abortion and congenital malformations, higher risk of preeclampsia and macrosomia, perinatal hypoxia and asphyxia, stillbirth, and neonatal complications ${ }^{3}$. However, the potential risks will also persist in the postnatal period. An inappropriate intrauterine environment may manifest with a variety of health problems throughout the child's life. In women with DM type 1, pregnancy may deteriorate the already existing complications.

The present study analyzed pregnancy outcomes in women with DM type 1 at a tertiary perinatal center.

\section{MATERIALS AND METHODS}

The investigation was designed as a retrospective cohort study conducted at the Clinical Department of Gynecology and Obstetrics, Split Univer- sity Hospital Center (Department). The study included data on all pregnant women with DM type 1 having delivered during a seven-year period (2009-2015) and those followed-up in 2015 having delivered in 2016. Control group included deliveries by healthy women that met other inclusion/exclusion criteria for the study and entered in the Department Delivery Room Protocol immediately after a study woman. Gestational age was expressed as completed weeks calculated from the last menstruation and corrected by

Insulin-dependent diabetes mellitus, as a significant factor for perinatal outcomes, can also follow the child throughout the life, and worsen the existing maternal complications, which gives this disease even greater importance and shows the need for a multidisciplinary approach.

ultrasound assessment when the difference exceeded one week. Fetal growth was evaluated using standards previously developed at our hospital $^{5}$. Ponderal index (PI) was calculated using the formula: $\mathrm{PI}\left(\mathrm{g} / \mathrm{cm}^{3}\right)=$ birth weight $(\mathrm{g}) / \mathrm{birth}$ length ${ }^{3}\left(\mathrm{~cm}^{3}\right)$. The neonates were then divided into groups of low (neonatal thinness), normal, and high (neonatal obesity) $\mathrm{PI}^{6}$.

\section{Statistics}

On data processing, Student's t-test for independent samples and $\chi 2$-test were used. The level of statistical significance was set at $p<0.05$. The results were shown as mean \pm SD or percentage. Statistical analysis was done by use of the MedCalc software (Version 19.6).

\section{RESULTS}

During the study period, there were 28.850 deliveries at the Department. Out of 87 pregnant women with DM type 1 hospitalized in pregnancy, 70 women were recorded by their names in the Delivery Room Protocol. In the remaining 17 (19.5\%) women, pregnancy outcome was unknown.

There were no multiple pregnancies, neonatal malformations or stillbirths in the investigation group. Pregnant women with DM type 1 were 
statistically nonsignificantly older $(30.7 \pm 5.2$ years-from 19 to 45 vs. $29.4 \pm 4.8$ years-from 16 to $40 ; \mathrm{t}=1.5 ; p=0.133)$. The proportion of primiparae (42.9\% vs. $57.1 \% ; \chi 2=2.8 ; p=0.092$ ) and neonatal sex distribution $(\chi 2=2.85 ; p=0.093$ ) were equal. In comparison with control group, the neonates born to DM type 1 mothers had a statistically significantly higher birth weight $(\mathrm{t}=2.2 ; p=0.031)$, with a higher rate of large for gestational age (LGA) babies ( $\left.\chi^{2}=9.4 ; p=0.002\right)$ and macrosomia $\left(\chi^{2}=4.1 ; p=0.033\right)$ (Table 1$)$. In the study group, there were five $(7.1 \%)$ neonates with birth weight greater than $4500 \mathrm{~g}$, whereas the highest birth weight recorded in the control group was $4330 \mathrm{~g}$. The mean gestational age at birth showed a statistically significant between-group difference (37.9 vs. 38.8 weeks; $t=3.6 ; p=0.004$ ). The rate of deliveries from $37^{\text {th }}$ to $39^{\text {th }}$ week of gestation was significantly higher in the study group $(84.3 \%$ vs.
58.6\%; $\chi 2=11.3 ; p=0.001)$, whereas the rate of deliveries at $>40^{\text {th }}$ week of gestation was sevenfold greater in the control group (5.7\% vs. $35.7 \%$; $\chi 2=12.8 ; p=0.001)$, as expected. The rate of cesarean section was nearly twofold greater in the study group ( $61.4 \%$ vs. $32.9 \% ; \chi 2=11.4 ; p=0.001$ ) (Table 2).

Comparison of the study group (DM type 1) primiparae and multiparae showed no statistically significant difference in any of the parameters (Table 3).

Considering regular surveillance in the study group, the number of hospitalizations ranged from one to eight; the highest proportion of women (22.9\%) were hospitalized five times, with the mean gestational age of 19 weeks at initial hospitalization. Four or less hospitalizations were recorded in $47.1 \%$, and 6 or more hospitalizations in $30 \%$ of women.

Table 1. Anthropometric characteristics and fetal growth evaluation in neonates born to DM type 1 mothers

\begin{tabular}{|c|c|c|c|}
\hline & DM type $1(\mathrm{~N}=70)$ & Control $(\mathrm{N}=70)$ & $p$ \\
\hline Birth weight $(\mathrm{g})$; mean \pm SD & $3650 \pm 605$ & $3428 \pm 591$ & 0.031 \\
\hline Birth length $(\mathrm{cm})$; mean $\pm S D$ & $50.7 \pm 2.19$ & $50.1 \pm 2.67$ & 0.156 \\
\hline Ponderal index, $\mathrm{PI}\left(\mathrm{g} / \mathrm{cm}^{3}\right)$; mean $\pm \mathrm{SD}$ & $2.78 \pm 0.31$ & $2.69 \pm 0.22$ & 0.050 \\
\hline $\mathrm{PI}<10^{\text {th }}$ percentile; $\mathrm{N}(\%)$ & $4(5.7 \%)$ & $4(5.7 \%)$ & 1 \\
\hline $\mathrm{PI}>90^{\text {th }}$ percentile; $\mathrm{N}(\%)$ & $25(35.7 \%)$ & $18(25.7 \%)$ & 0.202 \\
\hline Small for gestational age; N (\%) & $3(4.3 \%)$ & $6(8.6 \%)$ & 0.934 \\
\hline Large for gestational age; N (\%) & $17(24.3 \%)$ & $4(5.7 \%)$ & 0.002 \\
\hline Macrosomia (>4000 g); N (\%) & $17(24.3 \%)$ & $7(10 \%)$ & 0.033 \\
\hline APGAR score $\leq 7 ; \mathrm{N}(\%)$ & $2(2.8 \%)$ & $2(2.8 \%)$ & 1 \\
\hline Sex (male:female); N (\%) & $28: 42$ & $38: 32$ & 0.091 \\
\hline
\end{tabular}

DM type 1 = diabetes mellitus type 1

Table 2. Birth characteristics in DM type 1 mothers

\begin{tabular}{|c|c|c|c|}
\hline & DM type $1(\mathrm{~N}=70)$ & Control $(\mathrm{N}=70)$ & $p$ \\
\hline Birth weight $(\mathrm{g})$; mean \pm SD & $3650 \pm 605$ & $3428 \pm 591$ & 0.031 \\
\hline Birth length $(\mathrm{cm})$; mean $\pm S D$ & $50.7 \pm 2.19$ & $50.1 \pm 2.67$ & 0.156 \\
\hline Ponderal index, $\mathrm{PI}\left(\mathrm{g} / \mathrm{cm}^{3}\right)$; mean $\pm \mathrm{SD}$ & $2.78 \pm 0.31$ & $2.69 \pm 0.22$ & 0.051 \\
\hline $\mathrm{PI}<10^{\text {th }}$ percentile; $\mathrm{N}(\%)$ & $4(5.7 \%)$ & $4(5.7 \%)$ & 1 \\
\hline $\mathrm{PI}>90^{\text {th }}$ percentile; $\mathrm{N}(\%)$ & $25(35.7 \%)$ & $18(25.7 \%)$ & 0.202 \\
\hline Small for gestational age; N (\%) & $3(4.3 \%)$ & $6(8.6 \%)$ & 0.934 \\
\hline Large for gestational age; N (\%) & $17(24.3 \%)$ & $4(5.7 \%)$ & 0.002 \\
\hline Macrosomia (>4000 g); N (\%) & $17(24.3 \%)$ & $7(10 \%)$ & 0.033 \\
\hline APGAR score $\leq 7 ; \mathrm{N}(\%)$ & $2(2.8 \%)$ & $2(2.8 \%)$ & 1 \\
\hline Sex (male:female); N (\%) & 28:42 & $38: 32$ & 0.091 \\
\hline
\end{tabular}


Table 3. Comparison of birth characteristics and neonates born to DM type 1 primiparae and multiparae

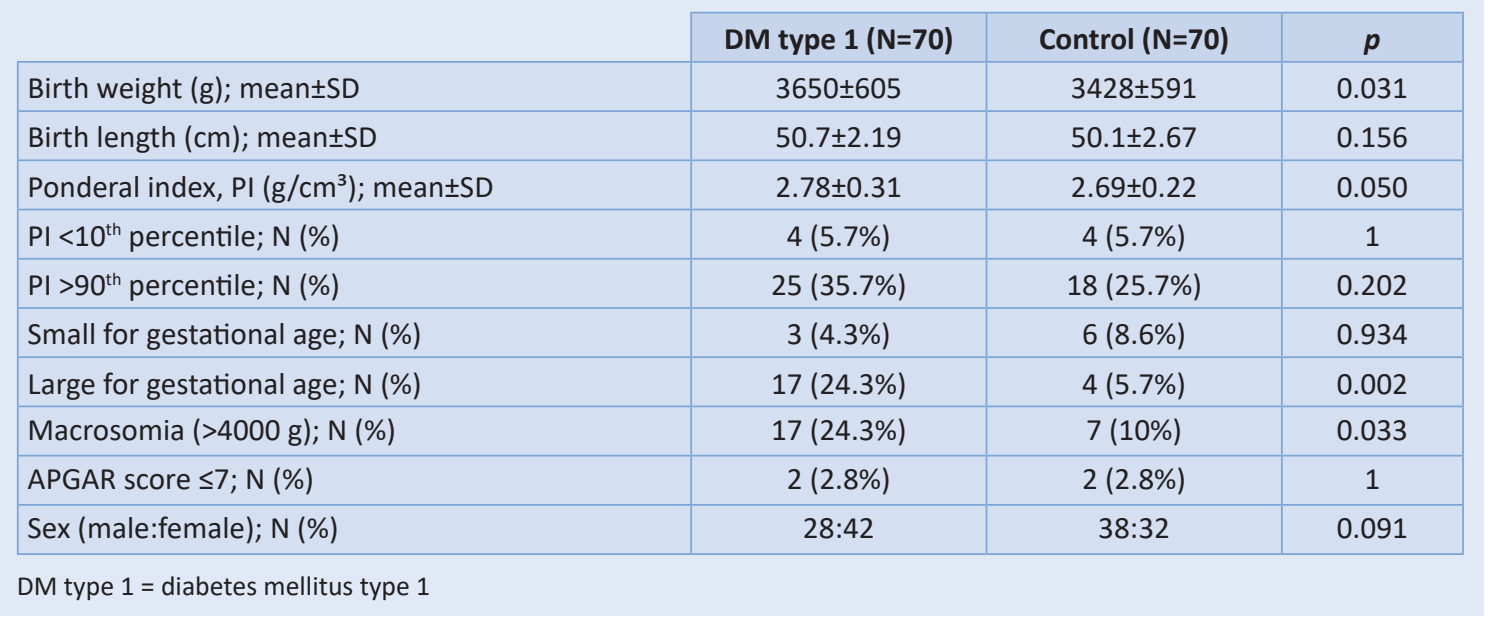

\section{DISCUSSION}

In the present study, the prevalence of pregnant women with DM type 1 was $0.2 \%(70 / 28,850)$, with a mean of 14.5 deliveries per year. Recent studies report on around 50 deliveries by DM type 1 women per year in Croatia, yielding a prevalence of about $1 \% 0^{4}$. Our study revealed a threefold greater proportion of DM type 1 pregnant women $(3.1 \%$ ) recorded at the tertiary center in Split with a >800,000 catchment population. The worldwide incidence of DM type 1 has been estimated to 1-50/100,000, with considerable regional and ethnic variations. Moderate DM type 1 incidence is reported in the population of northern Africa $(10-20 / 100,000)$, very low to low incidence in Asia $(<1-10 / 100,000)$, in North America similar to Europe, and high incidence in Australia and New Zealand (19-22/100,000). In Croatia, the prevalence of DM type 1 ranges from $6.5 \%$ to $7.5 \%$. Annual increase of $3 \%$ has been recorded in almost all populations observed ${ }^{7}$. According to Wahabi et al., pregnant women with DM type 1 are considerably older and more frequently multiparae than those from the general population ${ }^{8}$, whereas Temple et al. report on a higher proportion of primiparae ${ }^{9}$. In our study, diabetic women were only slightly older (30.7 vs. 29.4 years). This result could be attributed to the trend of giving birth at an ever-older age, observed in all women, along with the ever-earlier onset of DM type 1.

The expected rate of preterm deliveries in DM type 1 women is $22 \%-45 \%^{10-11}$. Lepercq et al. found $24 \%$ of preterm deliveries and correlated them with progressive nephropathy, preeclampsia and $\mathrm{HbA} 1 \mathrm{C}>7 \%$ as independent factors ${ }^{12}$. In the present study, the rate of preterm deliveries was considerably lower but without statistically significant difference, although nearly twofold greater as compared with the control group (10\% vs. 5.7\%). However, such a result may have been due to the small study sample and may reach statistical significance in a large-scale study. The same could apply to the equal rate of preeclampsia (5.7\% in both groups). In DM type 1 pregnancy, the expected incidence of preeclampsia is $15 \%-20 \%^{13}$. According to Vargas et al. and Sibai et al., the risk of preeclampsia in DM type 1 women is $12 \%-15 \%$ and $20 \%$, respectively ${ }^{10-11}$.

Accelerated fetal growth is one of the main features of pregnancy with DM type 1 . The increased and prolonged baseline and postprandial glucose supply to the fetus are especially pronounced towards the end of the second and at the beginning of the third trimester. Then the fetus starts secreting active insulin, thus modifying the entire metabolic pattern. This in turn results in fetal growth, which is predominated by cell hypertrophy and weight gain that is primarily dependent on the glucose to insulin relationship. In the conditions of diabetic pregnancy, stimulation of fetal pancreatic $\beta$-cells leads to hyperinsulinemia with consequential hyperplasia and hypertrophy of all cells and tissues except for the central nervous system ${ }^{4}$. Perinatal outcome of pregnancy with DM type 1 is associated with a 
higher rate of LGA and macrosomic newborns ${ }^{14}$. Many authors define macrosomia as a birth weight $>4000 \mathrm{~g}$, although $4500 \mathrm{~g}$ can also be found as a borderline value $\mathrm{e}^{8-14}$. According to Wahabi et al., the prevalence of macrosomia in children born to DM type 1 mothers is $11 \%$ and is 3.6-fold greater as compared with the general population $(3 \%)^{8}$. In our study, the rate of macrosomia was $24.3 \%$ and $10 \%$ in the study group and control group, respectively. The relatively low number of preterm deliveries must have contrib-

Only specialized tertiary perinatal centers have the preconditions for a standardized but at the same time individualized approach to pregnant women with DM type 1 , which are a relatively small but high-risk and medically specific population.

uted to such a high proportion but could not explain it completely. Birth weight $>4500 \mathrm{~g}$ was recorded in five $(7.1 \%)$ study group newborns, indicating that there were 12 newborns with birth weight of 4000-4500 g.

Neonatal PI was used to assess the birth weight to birth length proportionality. According to a Croatian study, PI was statistically significantly higher in neonates born to diabetic mothers than in those from the control group ${ }^{15}$. In our study, there was no statistically significant difference in PI between the groups. Roje et al. demonstrated correlation of $\mathrm{PI}$ and gestational age between 24th and 39th week ${ }^{16}$. Our result could in part be explained by the uniform gestational age at delivery in the study group (84.3\% within two weeks). In addition, appropriate surveillance and intensive follow-up throughout gestation must have contributed to it.

Placental volume, thickness and mass are significant factors of fetal growth and can serve as a measure of successful follow-up in diabetic pregnancy. Correlation has been reported of large placenta with macrosomia and fetal hypoxia ${ }^{6}$. The more so, in the conditions of early diabetic pregnancy, the initial development of the placenta is modified, thus possibly entailing various sequels later in life ${ }^{17}$. Proper placental development plays an active role in fetal programming and can influence diseases that may occur in adulthood ${ }^{18}$. Our study did not include data on the placenta, which we consider one of the major drawbacks of this investigation.

Diabetes mellitus type 1 per se is not an indication for pregnancy termination by cesarean section. Yet, it is the prevailing method of pregnancy termination in most institutions. Wahabi et al. perform cesarean section in 50\% of DM type 1 mothers, i.e. 2.5-times more frequently than in the control population ${ }^{8}$. Jensen et al. report on an even greater rate of cesarean section, as much as $55.9 \%$, in DM type 1 mothers versus $12.6 \%$ in the control group ${ }^{13}$. Our study revealed a $61.4 \%$ rate of cesarean section in DM type 1 women. The high rate of cesarean section in the control group (32.9\%) was nearly $75 \%$ greater than that recorded in the total population during the study period (18.6\%). The majority of cesarean sections in DM type 1 mothers are elective operations that are usually performed in the early morning, mostly as the first of the scheduled cesarean sections. Choosing control group subjects by the rule of the first woman entered in the Delivery Room Protocol after each study group woman increased the possibility for the control group to contain more elective cesarean sections than those recorded in the general population it is supposed to represent, and we are fully aware of this methodological bias. However, with this model we ensured representativeness in other elements, thus considering it least inappropriate among the compromise solutions available on designing the study.

According to Sokol et al., induced vaginal delivery in DM type 1 women can be considered with proven fetal pulmonary maturity and normal fetal growth. It should be reserved for cases free from any signs of fetal threat and generally accepted contraindications. It is optimal to plan induced vaginal delivery at 38 weeks of gestation, with the use of oxytocin infusion ${ }^{19}$. In our sample, prostaglandins were administered for labor induction in seven (25.9\%) of 27 mothers with vaginal delivery, whereas oxytocin infusion exclusively was used in the remaining 20 (74.1\%) mothers.

Wahabi et al. report on a threefold greater prevalence of stillbirth in diabetic mothers. Major ma- 
ternal and perinatal complications including asphyxia and perinatal death are in particular associated with macrosomia. The leading causes of perinatal mortality in children born to diabetic mothers are fetal asphyxia and congenital malformations. Asphyxia can be associated with angiopathic, morphological, and functional changes in the placenta. Congenital malformations result from inappropriate preconception workup and correlate positively with $\mathrm{HbA} 1 \mathrm{c}$ values ${ }^{8}$. In our sample, there was no case of perinatal death or congenital malformation, probably due to the small sample size and rare occurrence of these complications. A low Apgar score of $\leq 7$ (2.8\%) and prevalence of meconium stained amniotic fluid (7.1\%) did not differ between the groups. Comparison of primiparae and multiparae within the study group yielded no statistically significant difference, only the rate of cesarean section was higher in primiparae than in multiparae $(76.7 \%$ vs. 50\%). Persson reports that the risk of preeclampsia, neonatal mortality, and preterm delivery is lower, and the risk of LGA neonates higher in multiparae ${ }^{20}$. In our study, multiparae had 4.5-times more preterm deliveries, but the difference did not reach statistical significance, probably due to the small sample size.

\section{CONCLUSIONS}

Pregnancy in the presence of DM type 1 poses a complex perinatologic problem for both the mother and the child. Duration of the disease before pregnancy, the general health status of the mother, proper treatment, appropriate diet, and continuous correction of insulin dosage, quality fetal follow-up, along with the experience and knowledge of the staff and institution are the basic factors of the overall perinatal outcome. The knowledge of the fetal origin of adult diseases and the impact of epigenetics on placental development and function (placental programming) with all its sequels are additional elements in the understanding of risky pregnancies in general, and with DM type 1 in particular ${ }^{21,22}$. Maternal body composition and diet are thought to affect fetal development and programming as a result of both direct effects on substrate availability to the fetus and indirectly through changes in pla- cental function and structure ${ }^{23}$. Pregnant women with DM type 1 are a relatively small but highrisk and medically specific population. Their management must be comprehensive, well designed, standardized, and at the same time individualized. Only specialized centers with due experience have the preconditions for such an approach and can ensure appropriate team and multidisciplinary management. Our experience shows that pregnant women, those with chronic diseases in particular, are highly motivated to take due care of their health. DM type 1 is an excellent example where such a sudden and, unfortunately, frequently temporary motivation should be best utilized by the professionals and society.

\section{Acknowledgments}

i would like to express my deep gratitude to my mentor Professor Damir Roje for his patient guidance, enthusiastic encouragement, and useful critiques of this research work. I would also like to thank Professor Maja Radman and Professor Marko Vulić, for their advice and assistance in keeping my progress on schedule. My grateful thanks are also extended to Dr. Zoran Meštrović for his help in doing the data analysis.

Conflicts of interest: Authors declare no conflicts of interest.

\section{REFERENCES}

1. WHO [Internet]. Diabetes country profiles 2016-Croatia. Regional office for Europe WHO. c2016 [cited 2016 April 8]. Available from: http://www.who.int/diabetes/country-profiles/en/.

2. Cyganek K, Klupa T, Szopa M, Katra B, Małecki M T. Medical care of pregnant women with type 1 diabetes: current guidelines and clinical practice. Pol Arch Med Wewn 2013;123:1-2.

3. Đelmiš J. Skrb o dijabetičnim trudnicama. In: Đelmiš J, Ivanišević M, Metelko Ž (eds). Dijabetes u žena. Zagreb: Medicinska naklada, 2009;203-9.

4. Đelmiš J. Dijabetes i trudnoća. In: Kuvačić I, Kurjak A, Đelmiš J (eds). Porodništvo. Zagreb: Medicinska naklada, 2009;365-73.

5. Roje $D$, Tadin I, Marušić J, Vulić M, Aračić N, Vučinović M et al. Porodne težine i duljine novorođenčadi u Splitu: Opravdanost razvijanjanja vlastitih referentnih vrijednosti za ocjenjivanje fetalnog rasta. Gynecol Perinatol 2005;14:66-74.

6. Brett K E, Ferraro Z M, Yockell-Lelievre J, Gruslin A, Adamo K B. Maternal-Fetal Nutrient Transport in Pregnancy Pathologies: The Role of the Placenta. Int J Mol Sci 2014; 15(9):16153-85. 
7. HZJZ [Internet]. Poljičanin T, Smirčić Duvnjak L, Vinković $M$, Kolarić V. Šećerna bolest u Republici Hrvatskoj. c2005-14 [cited 2016 April 16]. Available from: https:// www.hzjz.hr/wp-content/uploads/2013/11/DMbilten-2005_2014.pdf.

8. Wahabi H A, Esmaeil S A, Fayed A, Al-Shaikh G, Alzeidan $R$ A. Pre-existing diabetes mellitus and adverse pregnancy outcomes. BMC Res Notes 2012;5:496.

9. Temple RC, Aldridge VJ, Murphy HR. Prepregnancy care and pregnancy outcomes in women with type 1 diabetes. Diabetes Care 2006;29:1744-9.

10. Vargas R, Repke J T, Ural S H. Type 1 Diabetes Mellitus and Pregnancy. Rev Obstet Gynecol 2010;3:92-100.

11. Sibai BM, Caritis SN, Hauth JC, MacPherson JP. Preterm delivery in women with pregestational diabetes mellitus or chronic hypertension relative to women with uncomplicated pregnancies. The National institute of Child health and Human Development Maternal-Fetal Medicine Units Network. Am J Obstet Gynecol 2000;183:1520-4.

12. Lepercq J, Coste J, Theau A, Dubois-Laforgue D, Timsit J. Factors associated with preterm delivery in women with type 1 diabetes: a cohort study. Diabetes Care 2004; 27:2824-8.

13. Jensen DM, Damm P, Moelsted-Pedersen L, Ovesen P, Westergaard JG, Moeller $M$ et al. Outcomes in type 1 diabetic pregnancies: a nationwide, population-based study. Diabetes Care 2004;27:2819-23.

14. Bérard J, Dufour $P$, Vinatier $D$, Subtil $D$, Vanderstichèle $S$, Monnier J C et al. Fetal macrosomia: risk factors and outcome. A study of the outcome concerning 100 cases
$>4500$ g. European Journal of Obstetrics \& Gynecology and Reproductive Biology 1998;77:51-9.

15. Đelmiš J, Buković D, Pfeifer D, Ivanišević M. Ponderal index and disproportionate fetal growth in IDDM pregnancies. Coll Antropol 1998;22:491-5.

16. Roje D, Banović I, Tadin I, Vučinović M, Capkun V, Barišić A et al. Gestational age - the most important factor of fetal ponderal index. Yonsei Med J 2004;45:273-80.

17. Gauster M, Majali-Martinez A, Maninger S, Gutschi E, Greimel PH, Ivanisevic M et al. Maternal Type 1 diabetes activates stress response in early placenta. Placenta 2017;50:110-6.

18. Kwon EJ, Kim YJ. What is fetal programming?: a lifetime health is under the control of in utero health. Obstetrics \& Gynecology Science 2017;60:506-19.

19. Sokol RJ, Chik L, Dombrowski MP, Zador IE. Correctly identifying the macrosomic fetus: Improving ultrasonography-based prediction. Am J Obstet Gynecol 2000;182: 1489-95.

20. Persson M, Pasupathy D. Effect of parity on pregnancy outcome in women with type-1 diabetes - A Swedish population-based study. J Diabetes Metab 2015;6:5.

21. Sallout B, Walker M. The fetal origin of adult diseases. J Obstet Gynaecol 2003;23:555-60.

22. Koukoura $\mathrm{O}$, Sifakis $\mathrm{S}$, Spandidos DA. DNA methylation in the human placenta and fetal growth. Mol Med Rep 2012;5:883-9.

23. Godfrey KM. The role of the placenta in fetal programming-a review. Placenta 2002;23SupplA:S20-7. 